\title{
Córdoba: paraestado, clientelismo y agentes de la violencia
}

\author{
Isaac Morales Pérez* \\ (imoralesp@unal.edu.co)
}

Articulo de reflexion recibido el 28/11/2014 y aprobado el 19/12/2014

Cómo citar este artículo:

MORALES PÉREZ, Isaac (2014). "Córdoba: paraestado, clientelismo y agentes de la violencia”. En: Trans-pasando Fronteras, núm. 6, pp. 37-54. Cali, Colombia: Centro de Estudios Interdisciplinarios, Jurídicos, Sociales y Humanistas (CIES), Facultad de Derecho y Ciencias sociales, Universidad Icesi.

\begin{abstract}
Resumen
El departamento de Córdoba ha sido un claro ejemplo de la debilidad estructural del Estado para ejercer el monopolio legítimo de la violencia e instaurar sus instituciones herméticas. Es por esto que acciones subversivas y, posteriormente, antisubversivas, tienen lugar en las tierras de los valles del Sinú y el San Jorge. Este contexto dio lugar al surgimiento de estructuras paraestatales en el interior del departamento, que permearon los ámbitos sociales, políticos, militares y económicos y, progresivamente, adquirieron reconocimiento por parte de la población y el Estado mismo en un principio, y luego fueron rechazadas por éste al considerarlas ilegales. En ese sentido, es pertinente la pregunta: ¿Ha sido Córdoba un ejemplo de estructura paraestatal de acuerdo con las definiciones teóricas? Este artículo busca responder a tal interrogante, por lo que, en primer lugar, realiza una aproximación teórica al concepto de "Paraestado",
\end{abstract}

\footnotetext{
* Estudiante del Departamento de Ciencia Política de la Universidad Nacional de Colombia, sede Bogotá D.C.
} 
como herramienta básica para entender los orígenes del fenómeno en sí. Posteriormente se presenta una diferenciación entre paraestado, paramilitarismo o autodefensas. En tercer lugar se establecen las definiciones, prácticas y relaciones entre clientelismo, paramilitarismo y agentes de la violencia en el terreno de estudio, como indicadores para definir la instauración de un paraestado en el departamento. Al final se presentan algunas conclusiones.

Palabras clave:

Estado, clientelismo, Córdoba, Paramilitarismo, Narcotráfico.

\section{Introducción}

Un fenómeno político y social ha caracterizado la historia reciente del Departamento de Córdoba. Ante la insuficiente capacidad del Estado para ejercer control sobre el territorio y detener la continuación y consolidación de la violencia enmarcada en la guerra antisubversiva, se organizaron grupos armados, un tipo de mercenarios, con intereses económicos, empresariales, militares y políticos, lo que dio pie a una suerte de diálogo y aceptación de otras formas de seguridad por parte del aparato estatal. Tales grupos, organizados como fuerzas al margen del Estado, pretendieron poder regional y local, ocasionando una crisis institucional con graves consecuencias sociales, entre las que sobresalen la pobreza y el marginamiento que caracteriza a buena parte de la población del departamento y la pérdida de legitimidad estatal.

En ese sentido, este trabajo tiene el objetivo de describir y explicar la forma e instrumentos empleados por dichos grupos al margen del Estado para acceder al aparato estatal en Córdoba y, hasta cierto punto, intentar reemplazarlo, desde sus orígenes hasta el año 2006.

\section{Paraestado: una aproximación teórica}

Este segmento tiene como propósito definir los preceptos teóricos con base en los cuales se desarrolla el presente trabajo. Originalmente, el término "paraestatal" hace referencia a instituciones u organizaciones que cooperan a los fines del Estado, sin hacer parte de la administración pública, es decir, complementan y en ocasiones sustituyen las labores del Estado, con pleno reconocimiento de éste. En Colombia este término se ha interpretado como ilegal, desconociendo la posible existencia de estas actividades en un ámbito legal. Regularmente, el Estado paralelo como se entiende en los estudios sobre Colombia, se 
concibe como una organización política, con alcance operativo y potencialidad logística para igualar al Estado legal, con pretensiones de ocupar su lugar en algún territorio en particular. Estas organizaciones en ocasiones reciben aprobación de la población al aportar beneficios y, por tanto, lograr legitimidad popular.

En Colombia, el surgimiento de estructuras paraestatales germina principalmente como fuerzas armadas alternas a las oficiales. Se consideran paraestatales al asumir funciones que le corresponden netamente al Estado, tales como el control territorial, la aplicación de normas de convivencia, la defensa y el control de la población civil bajo su mando, y la aplicación de justicia cuando los hechos lo requieran (Ortiz, 2009).

Este hecho puede ser visto con la lupa original del término como actividades que apoyan el cumplimiento de objetivos estatales, sin embargo, los grupos que desarrollan este tipo de acciones se enmarcan en el atropello a las instituciones, la violación de derechos humanos y la constante agresión a la población civil en defensa de algunos intereses particulares, contrario a los ideales de un Estado Social de Derecho. Estas estructuras organizadas por sectores de la población "crecen y se vuelven ejércitos móviles cuasiregulares que terminan asumiendo un importante papel político, militar y económico en la política de su país" (Kalyvas y Arjona, 2008).

Kalyvas y Arjona (2008) afirman que los orígenes de los grupos paraestatales, como los grupos paramilitares, pueden variar dependiendo del contexto social e histórico y el escenario político. Así, por ejemplo, en regímenes dictatoriales son organizados grupos alternos a las Fuerzas Militares legales para perseguir a los contradictores de un régimen. Claro ejemplo de esta forma de origen son las dictaduras en Argentina y Chile. Otro contexto se puede dar en casos de pretensiones coloniales y defensa de un territorio por parte de grupos paramilitares que ataquen movimientos de resistencia nacionalista. Un tercer tipo de condiciones que dan lugar al surgimiento de grupos paramilitares es el caso de la lucha de contrainsurgencia frente a guerrilla revolucionarias; el abandono del Estado obliga a la conformación de grupos armados de autodefensas constituidos por pobladores de aquellas regiones apartadas, que en su mayoría son apoyados por élites locales y regionales, ganaderos, terratenientes, narcotraficantes y las Fuerzas Armadas. De estas dos últimas formas de surgimiento de paramilitares se ocupa este trabajo. 
Presentada la tipología anterior, es posible asumir varias formas de nacimiento de organizaciones paraestatales en Colombia, una de ellas, entonces, a partir de la misma estructura del Estado. Los estudios sobre el origen de "paraestados" y del paramilitarismo en Colombia sugieren que fueron dos los hechos que motivaron el surgimiento de estas estructuras. Primero, la escasa y casi nula presencia del Estado en algunas regiones del país, un centro en la capital del país y una periferia en las regiones apartadas. Algunos académicos (Estrada, 2010) sugieren que la división del país por regiones y la accidentada geografía provocó la interrupción de los canales de comunicación entre el órgano central estatal y sus ramificaciones territoriales, lo que obligó la aparición de grupos de autodefensas que dominaban cierto territorio; esta primera causa va de la mano con la crisis de gobernabilidad o falta de legitimidad política del Estado legalmente constituido.

La segunda causa sugerida y analizada es la lucha de grupos de seguridad privada contra la insurgencia, algunos de ellos constituidos por voluntad de terratenientes, ganaderos o gamonales amenazados por las guerrillas, quienes se ocupan de contratar por seguridad a un grupo de personas armadas, una suerte de mercenarios; en su momento también se crean grupos con tintes reaccionarios encargados de destruir las bases sociales, ideológicas y políticas del movimiento Unión Patriótica (UP); y otros grupos paraestatales surgen como apoyo a las labores militares de las Fuerzas Armadas; al compartir enemigo, el Estado y los grupos de paramilitares desarrollan una relación de tolerancia, hasta el punto de brindar aval a tales organizaciones por medio de leyes y decretos.

Sin embargo, los paraestados también se sustentan en la crisis de gobernabilidad. Para Vargas Hernández (2008), la crisis de gobernabilidad democrática se caracteriza por la disfuncionalidad de las instituciones para solucionar democráticamente los conflictos que ponen en evidencia las tensiones existentes entre los requisitos de la democracia y los de la gobernabilidad. El autor, citando a Joan Prats, argumenta que el elemento común de la crisis de gobernabilidad es la incapacidad de las instituciones democráticas para asumir y procesar democráticamente el conflicto. El elemento común de la crisis de gobernabilidad es la falta de funcionalidad de las instituciones para dar solución a los problemas, por lo que se manifiesta a través de la debilidad de las instituciones. 
Las crisis de la gobernabilidad es resultado de las debilidades del Estado, disfuncionalidades de las instituciones económicas, políticas y sociales que erosionan los sistemas democráticos y dan lugar a regímenes híbridos. Resulta cuando los conflictos entre los diversos actores estratégicos tradicionales y emergentes cuestionan el equilibrio institucional del sistema sociopolítico debido, principalmente, a un deficiente sistema de institucionalización de reglas y procedimientos.

Ante la crisis generalizada de gobernabilidad y de legitimidad del Estado, junto a su incapacidad de satisfacer las demandas sociales, surge un estado amorfo, mutilado, inmerso en la corrupción y en la politiquería, donde se enmarcan de una manera difusa y confusa los límites de lo legal y lo legitimo de unas y otras organizaciones que se entrecruzan con facilidad produciendo actos aparentemente legales, pero no del todo lícitos y mucho menos ajustados a los más elementales requerimientos de la justicia legal (Ortiz, 2009:92).

Así, una consecuencia de las crisis de gobernabilidad se nota en el desempeño de las instituciones del aparato estatal. La flexibilidad y hasta la posible ausencia del Estado convierte en vulnerables las instituciones políticas a la ocupación de sus funciones por grupos ajenos a la administración pública y a la organización oficial.

\section{Gráfica 1.}

Evolución y fenómeno paramilitar

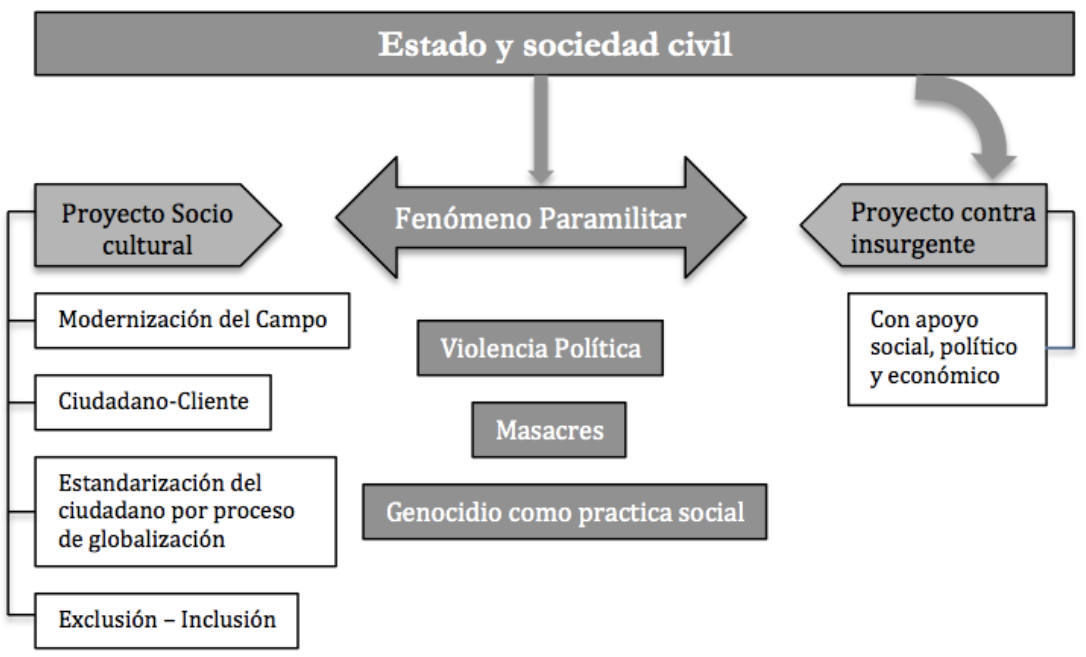

Fuente: Ayala (2011:53). 


\section{Gráfica 2.}

Evolución y fenómeno paramilitar

\section{Globalización Económica y Cultural}

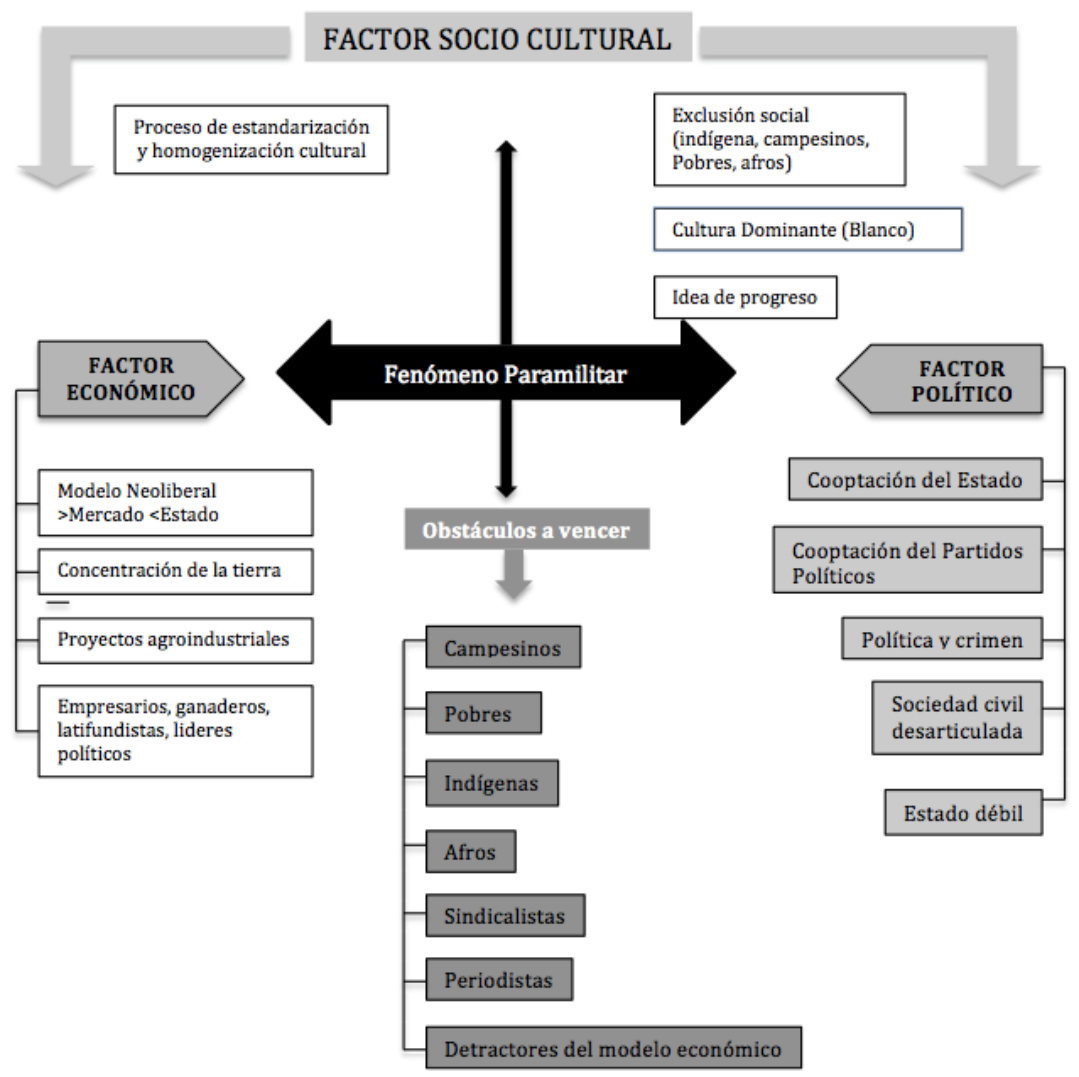

Fuente: Ayala (2011:53).

Ayala propone dos esquemas gráficos (ver gráficos 1 y 2) para representar los estadios de la evolución del fenómeno paramilitar, primero desde la perspectiva que señala al fenómeno como un asunto de violencia política originado por la histórica existencia de las guerrillas. En el segundo estadio, el autor sugiere ver este fenómeno como un cruce de intereses y de variables que lo vuelven más complejos.

Así, Ayala Osorio contempla dos etapas de consolidación del fenómeno paramilitar, la primera como convencionalmente se ha tratado: la lucha contrainsurgente y la deman- 
da de seguridad privada por parte de clases dominantes a falta del amparo estatal, apela a factores de las lógicas internas del país. El segundo estadio incluye aspectos del orden internacional, el neoliberalismo y la globalización como factores económicos que a su vez se condicionan por factores políticos, en la búsqueda y consecución del poder en ciertas zonas del país (Ayala, 2011:53-54).

Ávila (2010) afirma que la injerencia política de los grupos armados depende de tres factores esenciales, primero, la naturaleza de sus pretensiones, ya sean anti o pro estatal; segundo, el capital social que cultivan en determinado grupo poblacional, y tercero, su visión política y la capacidad de llevarla a cabo efectivamente; expresa que derrocar o capturar el Estado, no son los únicos objetivos de estos grupos; es posible afirmar que grupos como las FARC, en un principio con carácter antiestatal, pretendía boicotear y sabotear la institucionalidad del Estado, sin embargo a lo largo de su lucha se ha dado cuenta que una mejor opción es pretender dominar el poder y las instituciones como un parapoder local y regional, para desconocer y reemplazar el Estado y establecer sus condiciones en una zona del país. Al contrario de la acción de las FARC de sabotear el proceso político y, por tanto, al Estado, los grupos paramilitares apelan a la institucionalidad, pues creen en el status quo de este, sin abandonar sus propias convicciones de organización paralela, es decir, aceptan al Estado, ya que esta es una condición para caracterizarse como Paraestado. Estos últimos grupos buscan redefinir el concepto de Estado y apoyarse en el con fenómenos como la cooptación de poderes de gobierno y prácticas de ilegalidad como la ubicación de candidatos de sus preferencias en aparatos legislativos y administrativos (Avila, 2010:79).

Esta situación es definida por Garay, Salcedo, De León y Guerrero en el trabajo "La captura y reconfiguración cooptada del estado en Colombia" el cual referencia el concepto de reconfiguración cooptada del Estado (RCdE) como

la acción de organizaciones legales e ilegales que mediante prácticas ilegitimas buscan modificar desde adentro el régimen político de manera sistemática e influir en la formación, modificación, interpretación y aplicación de las reglas de juego y de las políticas públicas para obtener beneficios sostenibles y lograr que sus intereses sean validados política y legalmente, y legitimados socialmente en el largo plazo aunque estos no obedezcan al interés rector del bienestar social (2010). 


\section{¿Paraestados, paramilitarismo o autodefensas?}

Las Autodefensas Unidas de Colombia (AUC) fueron una compleja alianza de pequeños ejércitos surgidos desde finales de los años setenta, como es el caso de Ramón Isaza con sus Autodefensas del Magdalena Medio, y las fuerzas de control del Urabá y Córdoba de los años ochenta, lideradas por Salvatore Mancuso y Carlos Castaño, con una amplia proliferación de grupos armados por buena parte del país. Entre los años 95 y 98, Mancuso y Castaño se dedicaron a vender la "franquicia" AUC a los mejores postores y, por supuesto, que los narcos eran los mejores ofertantes, en un negocio en expansión y que requería de protección y garantías para su desarrollo. Esto coincidió con las negociaciones del Caguán entre el Presidente Pastrana y las FARC y allí encontraron el motivo político perfecto para revitalizar la dosis contrainsurgente de su proyecto. Así, no era posible ni admisible una negociación con las FARC, que no incorporara en sus debates a las fuerzas de la derecha más dura de Colombia

Las AUC, al mando de Castaño, buscaron presentarse como un movimiento con un mando único, un estado mayor, un estatuto de constitución y un régimen disciplinario común, conservándose como una estructura federada, con autonomía regional en lo referente a las finanzas, operaciones y comandancias. Fue así que en su segunda conferencia nacional deciden reformar y complementar el estatuto de constitución y régimen disciplinario de las Autodefensas Campesinas de Córdoba y Urabá (ACCU), como estatutos únicos de las AUC, a pesar de ser una organización con características conjuntas tendientes a definirse en un solo bloque evidenciado en sus cumbres periódicas del movimiento de autodefensas, al interior de esta se presentan diferencias entre las comandancias.

Ávila recoge el concepto de autodefensa y paramilitares dado por Romero Vidal, como aquellas fuerzas armadas irregulares que defendían un territorio (de agresiones) sin vocaciones expansionistas ni de incidencia en otras regiones, constituyendo fenómenos preferentemente locales. Por el contrario, los paramilitares son fuerzas armadas irregulares que obedecían a proyectos nacionales de expansión, con estructuras relativamente centralizadas y con un claro propósito contrainsurgente (OEI, 2009:26 en Lopez, 2010:93).

El autor resume las principales características de la Autodefensas, los Paramilitares y los Narcoparamilitares en la siguiente tabla, abordando su vocación, estatuto jurídico, años de acción, entre otros elementos: 
Tabla 1.

Autodefensas, Paras y Narcoparas

\begin{tabular}{|c|c|c|}
\hline Autodefensa & Paras & Narcoparas \\
\hline Ámbito: Local & Regional & Nacional \\
\hline $\begin{array}{l}\text { Vocación: seguridad privada e } \\
\text { individual. }\end{array}$ & $\begin{array}{l}\text { Vocaciones de control y expan- } \\
\text { sión regional. }\end{array}$ & $\begin{array}{l}\text { Modelo de control territorial, } \\
\text { social, político y económico, } \\
\text { con expansión nacional. }\end{array}$ \\
\hline Estatutos jurídicos: legal. & $\begin{array}{l}\text { Estatuto jurídico hibrido - } \\
\text { Convivir como figura legal } \\
\text { regional; bloques como figura } \\
\text { ilegal regional y AUC como } \\
\text { denominación ilegal nacional. }\end{array}$ & $\begin{array}{l}\text { Desmovilización pactada, } \\
\text { parcial. } \\
\text { Estatua militar ilegal, estatus } \\
\text { social legitimado, estatus } \\
\text { político legalizado. }\end{array}$ \\
\hline $\begin{array}{l}\text { Relación con el Estado: } \\
\text { Promovido por el Estado, } \\
\text { política de estado, } \\
\text { entrenamiento, armamento. }\end{array}$ & $\begin{array}{l}\text { Relación hibrida. No es política } \\
\text { de Estado, pero entre el } 94 \text { y el } 97 \\
\text { operan amparados por la figura } \\
\text { legal de las Convivir. En 1997, } \\
\text { como en 1987, se ilegalizan las } \\
\text { formas armadas de autodefensa } \\
\text { ante la evidencia de que son } \\
\text { careta de grupos narcotraficantes } \\
\text { y por las atrocidades cometidas. }\end{array}$ & $\begin{array}{l}\text { Ruptura con el estado político } \\
\text { nacional. Son declarados ilegales } \\
\text { y condenados oficialmente por } \\
\text { el estado central, pero el estado } \\
\text { político regional no rompe con } \\
\text { el fenómeno. Operativamente se } \\
\text { mantienen estrechas relaciones } \\
\text { con miembros de la fuerza } \\
\text { pública. }\end{array}$ \\
\hline Años 70-80 & Años 80-90 & Años $90 \mathrm{~s}-00 \mathrm{~s}$ \\
\hline $\begin{array}{l}\text { Denominación: Autodefensas } \\
\text { 1. Magdalena Medio } \\
\text { 2. Chepe Barrera (sur del } \\
\text { Magdalena y Cesar). } \\
\text { 3. Meta y Vichada. } \\
\text { 4. Ortega Cauca }\end{array}$ & $\begin{array}{l}\text { Transición: Autodefensas, } \\
\text { Paramilitares y Narcoparamili- } \\
\text { tares. La CIDH reseño en 1993, } \\
\text { entre otros: } \\
\text { Tangueros, Mochacabezas, } \\
\text { MAS, Los Magníficos, La } \\
\text { Terraza, ACCU }\end{array}$ & Convivir, ACCU, AUC. \\
\hline $\begin{array}{l}\text { Pro Estado } \\
\text { Demandan la presencia del Es- } \\
\text { tado, pero no son pro Estado en } \\
\text { el sentido de los grupos parami- } \\
\text { litares de Perú o Guatemala. }\end{array}$ & $\begin{array}{l}\text { Paraestado - Captura del } \\
\text { Estado } \\
\text { Tienen mas autonomía en su } \\
\text { financiación y operación, pero } \\
\text { su expansión y consolidación } \\
\text { dependen de su relación con el } \\
\text { Estado. } \\
\text { Elites subcontratan su segu- } \\
\text { ridad con el narcotráfico y el } \\
\text { Estado delega el monopolio de } \\
\text { la fuerza. }\end{array}$ & $\begin{array}{l}\text { Estado hibrido } \\
\text { Dos proyectos de Estado: } \\
\text { 1. El reconfigurado, que es } \\
\text { pro Estado pro Seguridad De- } \\
\text { mocrática que se consolido } \\
\text { en } 2002 \text {. } \\
\text { 2. El Estado mafioso, un esta- } \\
\text { do funcional al narcotráfico. } \\
\text { AUC-Bacrim. } \\
\text {-Reconfiguración de las fuentes } \\
\text { de poder nacional del Estado. } \\
\text {-Subcontratación de la seguri- } \\
\text { dad económica o política con el } \\
\text { narcotráfico. } \\
\text {-Expedir y consolidar un mode- } \\
\text { lo al menos hibrido. }\end{array}$ \\
\hline
\end{tabular}




\begin{tabular}{|c|l|l|}
\hline \multicolumn{1}{|c|}{ Autodefensa } & \multicolumn{1}{c|}{ Paras } & \multicolumn{1}{c|}{ Narcoparas } \\
\hline \multicolumn{1}{|c|}{ Ámbito: Local } & \multicolumn{1}{c|}{ Regional } & \multicolumn{1}{c|}{ Nacional } \\
\hline $\begin{array}{l}\text { Carácter contrainsurgente. } \\
\text { Promovidos como mecanismos } \\
\text { contrainsurgente por el Estado. }\end{array}$ & $\begin{array}{l}\text { Comparten el propósito anti } \\
\text { insurgente del Estado, pero tienen } \\
\text { su propio proyecto de estado: } \\
\text { Agrupar carteles narcotraficantes, } \\
\text { consolidar el control nacional } \\
\text { de la cadena del narcotráfico, y } \\
\text { revertir el contenido progresista } \\
\text { y democrático de la constitución } \\
\text { de 1991. }\end{array}$ & $\begin{array}{l}\text { Pierden la operación contra- } \\
\text { insurgente, pero capitalizan } \\
\text { El discurso anti insurgente. } \\
\text { solidación nacional del modelo } \\
\text { cooptado regional de Estado. }\end{array}$ \\
\hline $\begin{array}{l}\text { Elites terratenientes, ganaderos, } \\
\text { esmeralderos y gamonales se } \\
\text { agrupan en dos tipos regionales: } \\
\begin{array}{l}\text { 1. Elites legales que se ilega- } \\
\text { lizan ( Antioquia, Córdoba, } \\
\text { Costa Atlántica). }\end{array}\end{array}$ & $\begin{array}{l}\text { Elites económicas emergentes: } \\
\text { Narcotraficantes, y elite política } \\
\text { local y regional tradicional } \\
\text { usa a los paramilitares como } \\
\text { instrumento territorial, electoral }\end{array}$ & $\begin{array}{l}\text { Elites políticas y económicas } \\
\text { fusionadas, tradicionales y } \\
\text { emergentes, se consolidan } \\
\text { como factor de poder nacional. }\end{array}$ \\
y político. & \\
\hline
\end{tabular}

Fuente: Avila (2010).

Jairo Estrada en su libro "Derechos del capital. Dispositivos de protección e incentivos a la acumulación en Colombia”, propone un punto de vista diferente las ideas convencionales del nacimiento del paramilitarismo (abandono del estado y guerra contrainsurgnente), sugiere que el surgimiento de estos grupos paramilitares se da a raíz de la lucha de clases y de la necesidad de acumular capital por parte de unos pocos.

Estrada afirma que:

(...) Se ha producido un cambio en el balance de poder de clase. El bloque dominante, que también ha sufrido modificaciones en su conformación y en la correlación interna de fuerzas, ha logrado consolidar y afianzar su proyecto político, económico y sociocultural, conjugando el ejercicio de la democracia procedimental y de la legalidad burguesa con el consentimiento y la promoción del paraestado, de la parainstitucionalidad y de la violencia paramilitar. El producto histórico de esa conjunción ha sido la desestructuración de la clase obrera, del movimiento social y popular, así como de sus diversas expresiones organizativas, politicas y sociales; asimismo, la fragmentación de la resistencia, y la desarticulación en la dificil construcción de alternativas políticas. Pese a que se ha logrado una relativa cohesión en el 
bloque de poder, la posibilidad de un proyecto hegemónico y de dominación a largo plazo no parece suficientemente estable. Sus flancos débiles se encuentran en la persistencia del conflicto social y armado, en los reiterados y valientes esfuerzos de reconstrucción de la resistencia y alternativa, y en la fragilidad implícita de un proyecto que combina el discurso democrático con la ilegalidad y el crimen (2010:19).

Estrada ve el surgimiento del paramilitarismo como un germen mafioso que se acerca al Estado, lo que deja ver que la alianza entre lo legal y lo ilegal se convierte en fuerzas determinantes para las lógicas políticas, sociales y económicas del país. Así, agrega que:

La articulación entre las formas legales con las formas ilegales de la acumulación capitalista contribuyó hacia finales de la década de 1980 a la formación de un nuevo consenso a favor de las (contra) reformas estructurales y de la reestructuración neoliberal del Estado, y produjo una reconfiguración en el bloque dominante de poder, la cual se anunciaba ya desde la década de los setenta con el surgimiento de nuevos grupos económicos y la influencia creciente del capital financiero. Sólo que ahora se agregaba una alianza no santa -construida a lo largo de la década de los ochenta- entre sectores capitalistas legales con los empresarios de la cocaína. Se fortalecían así los rasgos criminales de la economía. Las estructuras mafiosas habían permeado igualmente las instituciones del Estado (todos los poderes públicos), incluidas las fuerzas armadas, los partidos políticos tradicionales y los políticos profesionales, y sectores de la iglesia. Se consolidaba así la estructura mafiosa de la formación socioeconómica.

De igual forma cita a Palacio y Rojas, quienes en 1989 aseguran que:

(...) el Paraestado no sólo tenía una fracción del capital que empezaba a ser predominante, sino que los empresarios de la cocaina, aliados con otras facciones del capital, empezaron a tener control territorial y bases sociales populares en algunas regiones del país (...) estamos frente a una especie de Paraestado que incluye una poderosa facción capitalista; un aparato represivo militar; gastos en bienestar social; control territorial regional y un restringido pero eficaz apoyo popular (2010:34-35). 
Finalmente, Estrada siguiere que Empresarios de la cocaína, estructuras mafiosas y paramilitarismo se constituyeron en formas criminales, en piezas del nuevo rompecabezas de la acumulación de capital en Colombia, basada ahora en la creciente articulación entre sus formas legales y sus formas ilegales. Ahí se encuentra uno de los principales rasgos de la producción de una nueva espacialidad capitalista en Colombia. En ese sentido, una explicación esencial del paramilitarismo consiste en su entendimiento como el otro brazo armado, junto con las Fuerzas Militares del Estado, de las tendencias recientes de la acumulación capitalista; contrario a la idea de sectores de la intelectualidad del establecimiento que desean explicarlo simplemente como una "reacción contra la violencia guerrillera".

\section{Clientelismo, paramilitarismo y agentes de la violencia en Córdoba}

Como se ha explicado hasta aquí, el sur de Córdoba y el Urabá antioqueño vieron nacer el paramilitarismo, primero como un grupo aislado de autodefensas y luego como un fenómeno generalizado en el país. Juan Carlos Garzón (2008) hace una aproximación general a los orígenes del fenómeno paramilitar en Colombia así:

Los orígenes del paramilitarismo actual han sido ligados a diversos momentos históricos que señalan de la misma manera varios "nacimientos". Como un antecedente se suele citar la experiencia de los llamados "pájaros" en la época de la Violencia. Estas bandas armadas al servicio del Partido Conservador llevaron a cabo una persecución contra los miembros del Partido Liberal, con complacencia y respaldo del establecimiento. Otros analistas se remiten al Decreto Legislativo 3398 de 1965, que fue convertido en legislación permanente por la Ley 48 de 1968, en el que se establecía el fundamento jurídico para la conformación de grupos de autodefensas bajo el auspicio y control de las Fuerzas Armadas. Sin ignorar esto, algunos académicos se han centrado en lo ocurrido en la década de los ochenta, principalmente en el departamento de Córdoba, donde las elites regionales reaccionaron a la intervención del Estado central -desde donde se comenzó a promocionar la reforma agraria-, así como a las actividades de extracción de recursos de la insurgencia como la extorsión y el secuestro. Desde esta perspectiva, las autodefensas tienen lugar como una respuesta a las acciones de las organizaciones subversivas, por parte de las elites locales quienes buscaron protegerse, dada la incapacidad del Estado de garantizar su seguridad. (2008:52). 
A partir de 1987, la labor de los Castaño contó con el apoyo de los terratenientes y la clase política tradicional cordobesa, Juan Manual "Mono" López logró reunir a los terratenientes de Córdoba en torno al proyecto paramilitar y fue electo alcalde de Montería para el período 1988-1990. Los López, Rodrigo García y Bernardo Vega apoyaron gremialmente a los Castaño a través de la federación de ganaderos y promovieron con la policía y el ejército las masacres de El Tomate, El Rincón y la desaparición en Tenerife de siete personas en 1989. Como lo muestra Mauricio Romero:

Para 1987, el escenario de la guerra sucia estaba montado. El ejército inauguró la XI Brigada en Montería, Fidel Castaño armó su ejército privado y los ganaderos cambiaron el destino de sus aportes. De la vacuna ganadera se pasó a los "aportes de seguridad" (Garzon, 2008:60)

Es necesario remitirse a una definición del término "clientelismo" para conocer las trayectorias que se revisan en este segmento del texto. Wills y Rivera (2009) sostienen que el clientelismo es una relación dinámica que va transformándose según el contexto y los sujetos que la componen. El clientelismo es una relación entre elector y elegido; bases y cuadros partidistas; individuo, políticos y funcionarios públicos que se desenvuelven necesariamente en un régimen que se define a sí mismo como democrático porque recurre periódicamente al ritual electoral para renovar su personal político. Las autoras afirman que al ser una manera específica de articular al individuo con las instituciones y al votante con sus representantes, el clientelismo se convierte también en una intermediación entre sociedad y Estado y entre sectores sociales y ámbito público (2009).

Esta relación en lugar de abogar por concretarse entre organizaciones sociales y Estado impersonal, en búsqueda de un bien colectivo, se forman relaciones de intereses particulares de familias, con los votantes, personalizando la política, provocando el tambaleo de las instituciones, de lo público y de las estructuras de partidos. Un compromiso con el político a cambio de un "favor". Así pues, el clientelismo es una relación de intercambio entre sectores sociales y padrinos políticos con trayectoria en la vida política estatal.

Una clara relación entre clientelismo y paramilitares se nota en la influencia de las AUC en el territorio cordobés. La asociación entre la casa Castaño y Salvatore Mancuso condujo a la creación de las AUC, un proyecto paramilitar nacional que busca dotarse de 
organización jerárquica y coherencia política. Mancuso permitió las conexiones entre el paramilitarismo en Antioquia y las elites cordobesas. Una segunda etapa de expansión paramilitar se presenta con el paso del control territorial a la pretensión de control político, lo que enfrentó a Mancuso y la elite política cordobesa. Algunas versiones recogidas en terreno señalan que los líderes políticos de Córdoba no tenían la capacidad de resistirse a la influencia de los señores de la guerra. Por ejemplo, entre Juan Manuel López Cabrales y Salvatore Mancuso hubo una rivalidad personal marcada por sus propios intereses, políticos o económicos. El poder de las armas y el terror de Mancuso y sus hombres puso en jaque el dominio político de la familia López Cabrales.

Los paramilitares buscaban legitimidad y reconocimiento por parte del pueblo, tanto así que, "La sociedad los veía como los salvadores porque la gente podía ir a sus fincas y ellos se creyeron el cuento". A medida que los paramilitares se hicieron a más recursos armados y estratégicos, ganaron más peso para inclinar la balanza política a su favor, determinando nombramientos burocráticos e infiltrando el aparato estatal” (Wills y Rivera, 2009:138).

El poder se expandió a unos sectores de la sociedad que les otorgarían legitimidad y representatividad y control social, cuyo ejemplo emblemático fue lo ocurrido en la Universidad de Córdoba. En primer lugar por eliminar cualquier brote de izquierda, una hipótesis valida pero incompleta, hacer proselitismo, reclutamiento, generar cuadros políticos y beneficios burocráticos aprovechando el presupuesto, acaparando en sentido práctico una institución más del Estado, que les ofrecía acceso a la burocracia y así a una red clientelista que le podría generar apoyo.

La Universidad de Córdoba, el principal centro de educación superior público del departamento, se convirtió en un centro de operaciones de los grupos paramilitares, quienes se apoderaron del claustro al manejar a su interés la organización burocrática, filtrando el perfil de sus empleados. La toma de decisiones debía ser aprobadas por el hoy desmovilizado cabecilla paramilitar, Salvatore Mancuso. Lo anterior permite afirmar que los papeles del clientelismo se invierten en la relación político-clientela, la fuerza paramilitar toma el rol de político y los políticos asumen el rol de clientela, es decir, los paramilitares aprovechan la plataforma política de las fuerzas tradicionales de trayectoria y reconocimiento regional para consolidar su poder en la región. 


\section{Agentes de la violencia: Estado y Grupos Paramilitares}

El Estado es un agente de la violencia al poseer el monopolio legítimo de las armas; una estructura que pretende brindar seguridad y defensa en el ámbito militar y social. Sin embargo, el Estado colombiano se ha caracterizado por descuidar regiones apartadas del centro de gobierno. Esta incompetencia en cuanto su presencia implica la necesidad de concebir formas alternas para conseguir sus objetivos como Estado plenamente constituido. El convulsionado pasado en el que la clase política luchaba constantemente por el poder, en una puja bipartidista, genera el descuido de las funciones sociales, económicas y políticas del Estado; la violencia se vuelve un hecho común esparcido por todo el territorio nacional.

El Estado, incompetente para solucionar esta situación acude a formas "alternas" para el apoyo en el cumplimiento de sus funciones, por lo que reconoce y patrocina la formación de grupos violentos. Conocer y patrocinar la formación de grupos violentos significa poseer un porcentaje de culpabilidad en las acciones violentas llevadas a cabo en el departamento.

Después de la muerte de Pablo Escobar, los Castaño expanden su poder y dominio, de "los Tangueros" a las ACCU. La corte suprema declaró ilegal las autodefensas en 1989, sin embargo, el gobierno de Ernesto Samper por medio del Decreto 356 de 1994 se autorizó la creación de cooperativas armadas civil, las convivir, con armas de corto y largo alcance, como fuerzas paralelas al Estado con fines contra la guerrilla, Uribe como gobernador de Antioquia conoce el hecho y lo avala. Todas las convivir del Urabá y el resto del país como una federación se unen en las AUC (Ferry, 2012)

Las primeras muestra de autodefensas causaron terror desmedido en el departamento, ejemplo de esto son algunas de las masacres ejecutadas. La mejor esquina, el 3 de abril de 1988, corregimiento de Buenavista, Córdoba, en cabeza de los Castaño, que asesinan a 27 personas durante la celebración del domingo de resurrección. El tomate, el 30 de agosto de 1988, corregimiento del municipio de Canalete, unidades paramilitares asesinaron 16 campesinos, ejecutaron violaciones al derecho internacional humanitario, a través del uso de granadas y ráfagas de ametralladora contra la población civil. Los grupos paramilitares no solo permearon la estructura política, burocrática y económica del departamento de Córdoba, sino que también alteraron la vida social de sus pobladores. 


\section{Conclusiones}

A lo largo del presente trabajo se presentó la definición de "Paraestado" acuñada por distintos autores, concepto que se relaciona con el surgimiento y consolidación de estructuras políticas y organizadas socialmente que si bien no remplazan la institucionalidad estatal, la acompañan y cooperan con ella. También se afirmó, con base en estudios recientes, que la crisis de gobernabilidad, la debilidad del Estado y la estructura económica en torno de la acumulación de capital determinaron el surgimiento de organizaciones con características de paraestatalidad en Colombia.

De acuerdo con estos esquemas, se puede afirmar que Córdoba, unidad de análisis de este trabajo, se convirtió en un Paraestado, con todas las características de este tipo de organización política, al ser invadido por grupos de fuerzas militares y políticas, paralelas a la estructura legal del estado. Un hito de esta afirmación es la firma del reconocido "Pacto de Ralito" en 2001, en el que en cabeza de Mancuso, se citan a políticos y funcionarios públicos de varias regiones de la costa norte del país, con la intención de "refundar la patria".

\section{Bibliografîa}

AVILA, A. (2010). "Injerencia Politica de los grupos ilegales". En C. Lopez, Y refundaron la patria.... Bogotá D.C: Corporacion Nuevo Arcoiris. Congreso Visible. Dejusticia. Grupo Metodo. MOE.

AYALA, G. (2011). Paramilitarismo en Colombia. Mas allá de un fenómeno de violencia politica. Bogotá D.C: Universidad Autonoma de Occidente.

CAMACHO, A. Duncan, G. Steiner, C. Vargas, R. Wills, M. (2009). A la Sombra de la Guerra ilegalidad y nuevos ordenes regionales en Colombia. Universidad de los Andes. CESO. Bogotá D.C.

CEPEDA, I y Rojas, J. (2008) A las puertas de El Uberrimo. Debate. Bogota. D.C.

DANE. (25 de Mayo de 2012). Cuentas departamentales base 2005. Recuperado el 12 de Julio de 2014, de DANE: http:/www.dane.gov.co/files/investigaciones/pib/ departamentales/B_2005/Resultados_2010.pdf 
ESTRADA, J. (2010). Derechos del capital. Dispositivos de protección e incentivos a la acumulación en Colombia. Bogotá D.C: Universidad Nacional de Colombia.

FERRY, S. (2012). Un manual del conflicto colombiano, VIOLENTOLOGÍA. Bogotá D.C: Carvajal.

GARAY, L. Salcedo, E. De León, I. Guerrero, B. (2008). La captura y reconfiguración cooptada del estado en Colombia. Grupo transdisiciplinario de investigación en ciencias sociales, MÉTODO. Fundación AVINA. Corporación Transparencia por Colombia. Bogotá, Colombia

GARZON, J. C. (2008). "La complejidad paramilitar: una aproximación estratégica". En: A. Rangel, El poder paramilitar (pág. 52). Bogotá D.C: Planeta. Fundacion Seguridad y Democracia.

GUTIÉRREZ, F. (Comp.) (2001). Degradación o cambio, evolución del sistema político colombiano. Editorial Norma. Bogotá D.C

IPSOS- Napoleón Franco (2007). Estudio de Opinión sobre el Paramilitarismo y la "Para-politica" en Colombia.

KALYVAS, S., y Arjona, A. (2008). "Paramilitarismo: una perspectiva teorica". En: A. Rangel, El poder paramilitar. Bogotá D.C.: Planeta. Fundacion Seguridad y Democracia.

LEAL, F. (ed.) (2007). En la encrucijada: Colombia en el siglo XXI. Centro de estudios Sociales de la Universidad de los Andes. Editorial Norma. Bogotá, Colombia.

LOPEZ, C. (2010). Y refundaron la patria... De cómo mafiosos y politicos reconfiguraron el Estado colombiano. Bogota DC: Debate.

ORTIZ, W. (2009). Los paraestados en Colombia: fundamentacion teorica y salidas politicas. Medellin, Colombia: Universidad Autonoma Latinoamericana.

RANGEL, A. Ramírez, W. Garzón, J. Kalyvas, S. Arjona A. Cuéllar, F. Cubides, F. (2008). El Poder Paramilitar. Fundación Seguridad y Democracia. Colombia. 
VALENCIA, León y Observatorio de Conflicto Armado (2007). “Los caminos de la alianza entre los paramilitares y los políticos León Valencia y Observatorio del Conflicto Armado". En: Romero Mauricio (Coordinador). Parapolítica. La ruta de la expansión paramilitar y los acuerdos políticos. Bogotá: CEREC - Corporación Nuevo Arco Iris.

WILLS, M., y Rivera, M. (2009). Poder, familia y clientelismo en Montería, Córdoba (1950-2008). Visibilizacion y ascenso de las mujeres en contextos totalitarios. Bogotá D.C.: Ediciones Uniandes. 